\title{
Android Application to Detect Cat Disease Using an Expert System
}

\author{
Alvina Aulia ${ }^{1}$, Yogi Udjaja ${ }^{1,2, *}$, Irma Kartika Wairooy ${ }^{1}$, Adithia Panji Hutama ${ }^{1}$, Dinar Khansa Shabira ${ }^{1}$, Sabilal Muhtadin ${ }^{1}$ \\ ${ }^{1}$ Computer Science Department, School of computer Science, Bina Nusantara University, Jakarta, Indonesia 11480
}

${ }^{2}$ Ekspanpixel, Jakarta, indonesia 11480

\begin{tabular}{l} 
A R T I C L E I N F O \\
\hline Article history: \\
Received: 26 April, 2019 \\
Accepted: 19 July, 2019 \\
Online: 24 September, 2019 \\
\hline Keywords: \\
Cat \\
Diagnosis of Cat Disease \\
Android Application
\end{tabular}

A B S T R A C T
The purpose of this research is to develop an android application named "TANYA MEOW"
which can be used by cat owners to detect the diseases that their cats suffer based on visible
symptoms. The cat owners need to answer questionnaire to detect what disease is suffering
by their cat. The result of the disease is also accompanied by the first treatment that cat
owners can do to treat their cats. In addition, this application also has a feature that
provides information, tips and tricks in cat care. The research methods used to analyze the
development of this application are literature study through books, journals and e-books.
Furthermore, observation, distribution of questionnaires for data collection and interviews
to ensure data accuracy. We also make comparisons with applications that have similar
concepts and features similar to our application. The research method used for the
development of this application is waterfall that has five stages, requirements definition,
system and software design, implementation and unit testing, integration and system testing
and operation and maintenance. The results obtained from this writing show that the owner
of the cat can feel the ease in detecting and knowing the disease from their cats who are
sick, also getting knowledge on how to take care of cats in a good way.

\section{Introduction}

In the era of rapid development of smartphones, where pet owners are now so enthusiastic to see the behavior of their pets and capture this moment through the camera on the smartphone. Animal owners also often use smartphones to access various articles on the internet to recognize the nature, behavior, and symptoms of the disease [1]. However, some articles are not actual and true for the health of their pets. Animal owners need a good source and useful media to see the condition of their pets. Thus, we developed an app that focused on cat that could allow users to find ways to prevent and perform first action on their beloved cat when strange symptoms seen in cats or cats are already infected by an illness as well as providing tips and tricks in the form of actual information in the care of cats [2]. Therefore, this application can be one of an application or a media to help cat owners in doing the right action based on the illness suffered in the form of useful and actual information for their cat [3].

Therefore, the formulation of our problem in making this research is how cat owners can know the diseases suffered by cats

*Yogi Udjaja, Jakarta, Indonesia 11480, +62 898268 3399,

udjaja.yogi@gmail.com,yogi.udjaja@binus.ac.id

www.astesj.com

https://dx.doi.org/10.25046/aj040521 based on visible symptoms, how cat owners can find information about handling the disease, first aid on what to do when the cat is sick, how cat owners can find information about the prevention of diseases that must be done when the cat is sick and how cat owners can find out information about tips and tricks in cat care using android based smartphones [4]. From the problems in, it can be concluded that our goal in making this application is to create an application that can help cat owners to know the type of cat disease based on visible symptoms, provide information that can help cat owners to know easily about the handling and first aid against cat, providing information that can help cat owners find out easily about cat's disease prevention and provide information on android smartphones that can help cat owners find out easily about tips and tricks in cat care [5]. The benefits of the for cat owners to rapidly diagnose cat diseases, accurately and interactively, help cat owners to take early action against diseases suffered by cats, provide detailed information on cat disease prevention and increase knowledge to owners cat about tips and tricks in cat care.

\section{Why Cat?}

Cats are animals that have many advantages. His fur is soft, his body shape is adorable, his spoiled nature always makes him love to stroke and play with him. In addition, the behavior of cats 
that are very funny while joking makes their lovers entertained. Initially, cats come from the wild, then slowly undergo the process of dosmetication. Now, cats become pets that are very close to humans [6].

According to ref. [7], the following are examples of diseases that can be suffered by cats:

\section{- Cat Diarrhea}

This disease is a disease of increased fluid in the stool and increased frequency of defecation. Mild diarrhea is usually caused by changes in food, too much eating, and stress disorders. Conversely, severe diarrhea is caused by an increase in peristaltic movements of the intestine so that the food material comes out faster, food does not have much time to digest properly.

Clinical symptoms include: runny diarrhea, very runny stools. Cat feces smell bad. The cat vomits and refuses to drink. To prevent diarrheal disease, clean the place to drink and place food with disinfectants. For treatment you can use worm medicine and can be injected with vitamin B12 to increase appetite.

\section{- Cat Lice}

Lice in cat are caused by Ctenocephalides felis. Adult fleas can live up to around 115 days in a cat's body, and will die soon if they are not in the cat's body for only 1-2 days. The survival of adult lice depends on environmental conditions, including humidity, cat's breath, and cat's body vibration.

The initial symptoms of cat lice are just normal itching. All fleas will irritate your cat's skin. Sometimes because of the large number of fleas and itchiness, cats scratch their bodies, especially in the nape of the neck, ears and base of the tail. Prevention and treatment efforts can be with flea drugs and with lice exterminator shampoo.

\section{- Cat Mite}

This disease is generally caused by Otodectes cynotis. The life cycle from eggs to adults takes around 21 days. Mites often attack young cat ears. They eat secretions in the ear canal or flaking skin. The initial symptoms of cat mite are shaking their heads and scratching their ears, sometimes cats rub their ears, walls, or soil. For symptoms that are severe the cat bends and loses balance and sometimes rolls over. In the ear hole there is dry or damp blackish brown dirt and thickening of the skin.

Symptoms can continue with the release of a runny or thick liquid from the foul-smelling cat's ears and yellow to greenish red. Prevention efforts that can be done is by washing or changing the cat's bed, every 3-4 weeks the cat's ear is given drops, mite exterminator, cleaning the hole.

\section{- Cat Otitis}

This disease is an infection of the ear canal, which is a connecting area between the outside of the ear and ear drum. Symptoms of itching in the ear. The cat tries to shake its head, scratch, and sometimes rubs the ear against the cage wall until a wound appears, the ear hole swells, and the cat feels pain when the part is held. The skin of the inner ear is reddish, the skin will thicken and scaly, pus and bumps sometimes appear.

Prevention that can be done is by eradicating ticks and fleas that attack the cat's cage. Clean cat ears once a week. Treatment can be adjusted to the cause. For bacteria given antibiotics, for fungi given antifungals, for allergies can be given antihistamine drugs.

\section{- Cat Constipation}

The first cat constipation is found in food quality. Cats are very short of crude fiber and drink less, including eating too much meat. Another cause is the age of the cat, where the intestinal muscles have started to weaken so that the activity decreases.

The symptoms are difficulty defecating Anus swells, reddish dirt and sometimes accompanied by blood and during bowel movements, cats always try to push, but dirt fails to come out. Prevention that can be done is to provide a balanced diet that is sufficiently like rough fiber. Always provide clean and fresh water so the cat is not short of fluids. The first treatment for mild constipation is to give laxative medication. Use laxatives to remove hard feces quickly.

\section{Problem Statement and Preliminaries}

The first research method used is data collection methods, including literature study conducted to find sources and references related to the development of Android-based mobile applications. Second, observations made by observation to animal clinics. Observation is done by recording the implementation of activities in the field, especially at the time of the interview. Third is the distribution of questionnaires conducted as a method of data collection. Fourth is interview conducted to the veterinarian to ensure the truth of data about the disease as well as symptoms in the cat and asking information that is needed to be implemented in the application so that the data obtained are actual. Then an application is formed using an expert system [8]. The last is the comparison of applications performed by taking reference applications that have the same characteristics and within the same category that will be an important source for the progress of this research.

\section{Analyze User Needs}

In the process of collecting data for the needs of users, we used questionnaire method. The questionnaire are distributed to 124 respondents on September 11, 2017 to September 14, 2017. Here are the results of the questionnaire:

1. $100 \%$ of respondents have cats.

2. Of the total $100 \%, 39.5 \%$ have domestic cats, $33.9 \%$ have Persian cats, $6.5 \%$ have cats, $2.4 \%$ have Maine Coon cats and $17.7 \%$ have cats other races.

3. $78.2 \%$ of respondents keep cats inside their house and $21.8 \%$ keep outside their house.

4. $73.4 \%$ of respondents answered that their cats rarely get sick, $21 \%$ are quite frequent and $5.6 \%$ are often sick.

5. $41.1 \%$ of respondents were browsing about diseases and handling it by their own when their cats were sick, $35.5 \%$ 
were taken to the doctor, $15.3 \%$ asked the closest relation that had a cat and 3.2\% answered to be silenced until healed by itself.

6. Of $100 \%$ of respondents as much as $83.9 \%$ responded confused when their cat changed behavior and as much as $16.1 \%$ answered "No".

7. $38.5 \%$ of respondents know the disease in cats and symptoms and as much as $61.5 \%$ do not know the disease and the symptoms in cats.

8. With a total percentage of $100 \%, 96 \%$ are interested in using application that can detect disease, provide tips and tricks and first aid information on cats.

Table 1: Similar Application Comparisons

\begin{tabular}{|c|c|c|}
\hline Comparison & Cat care & Pet care \\
\hline $\begin{array}{l}\text { Platform } \\
\text { type }\end{array}$ & Android & Android \\
\hline Internet & Requires internet & No need for internet \\
\hline Notification & Do not have tutorial & Do not have tutorial \\
\hline Article & $\begin{array}{l}\text { Does not have article } \\
\text { features }\end{array}$ & Has article features \\
\hline $\begin{array}{l}\text { Background } \\
\text { Music }\end{array}$ & $\begin{array}{l}\text { Do not have } \\
\text { background music }\end{array}$ & $\begin{array}{l}\text { Do not have } \\
\text { background music }\end{array}$ \\
\hline $\begin{array}{l}\text { Disease } \\
\text { Diagnosis }\end{array}$ & $\begin{array}{l}\text { Does not have a } \\
\text { diagnosis of disease } \\
\text { features }\end{array}$ & $\begin{array}{l}\text { Does not have a } \\
\text { diagnosis of disease } \\
\text { features }\end{array}$ \\
\hline $\begin{array}{l}\text { Handling } \\
\text { Disease }\end{array}$ & $\begin{array}{l}\text { Does not have a } \\
\text { disease handling } \\
\text { feature }\end{array}$ & $\begin{array}{l}\text { Does not have a } \\
\text { disease handling } \\
\text { feature }\end{array}$ \\
\hline $\begin{array}{l}\text { User } \\
\text { Interface }\end{array}$ & $\begin{array}{l}\text { Easy to understand } \\
\text { interface and } \\
\text { interactive menu }\end{array}$ & $\begin{array}{l}\text { Simple and easy to } \\
\text { understand interface }\end{array}$ \\
\hline Advantages & $\begin{array}{l}\text { Contains news about } \\
\text { cats }\end{array}$ & $\begin{array}{l}\text { Contains articles, tips } \\
\text { and tricks about pets, } \\
\text { including cats }\end{array}$ \\
\hline
\end{tabular}

\section{Similar Application Comparison Analysis}

Comparison of similar applications is adopted from ref. [9], this model is a comparison of features to the advantages possessed by each application analyzed, so that the application made can be developed in accordance with the results of comparison of similar applications.

Based on comparison of similar applications, the target is the Android platform, to make it easier for users of the application to not need the internet, to have tutorials, to feature articles, and to make music background interesting, then to diagnose diseases, to treat diseases and to make the user interface easy to understand, interesting and interactive. So overall the advantages possessed compared to other applications are having a feature of disease diagnosis, disease management and containing articles about tips and tricks in maintaining cats.

\section{Architecture Software}

Architectural models that are made almost similar to architectural ref. [10], what is different is the content in it, where there is an expert system to detect cat disease. Then, for the user experience, use the model created by ref. $[11,12]$.

\section{Software Functions}

1. Cat's Registration

This feature is used for cat registration by filling in data on registration form such as name, gender, month of birth and race. Users can register one cat or more.

2. Tanya Meow (Diagnosis of Disease)

This feature is used to diagnose the disease in cats based on visible symptoms. First, the user will choose what parts of the body that cause symptoms of the disease. Then, users are given some questions based on these symptoms and given the diagnosis of a cat-like disease and the first aid on what to do to treat their cat.

3. Info Meow

This feature contains information, articles and tips and tricks how to care for a good and true cat. The menu is divided per-category for easy user in navigating.

4. $\mathrm{P} 3 \mathrm{~K}$

This feature contains treatment of the diseases that can be suffered by cats. The menu is divided per-category for easy user in navigating.

5. Cat Disease's History

This feature is used to view the list of selected cat catastrophes that users have previously done in the menu "Tanya Meow".

\section{Main Results} Meow:

Below is the display of features or app results of Tanya

- Fig.1 The main menu contains the Registrasi, Pilih Kucing, Tanya Meow, Info Meow, P3K, Riwayat, and Pengaturan menu. This page provides information to users about what features can be used on the main menu page.

- $\quad$ Fig.2 This page contains forms to fill with the names of cats, gender, month of birth, race of cats, and also choose the cat icon. The cat registration page helps the user create a cat profile. On the Pilih Kucing page, the user can see the registered profile and choose the desired cat profile. This page allows the user to choose the cat that will be used.

- $\quad$ Fig.3 Choosing a cat profile or deleting a pre-registered profile can be done on the Konfirmasi Pilih Kucing page. This page helps the user to make choices based on the user's wishes.

- $\quad$ Fig. 4 Tanya Meow page is a diagnostic page that helps the user to know the cat's disease. 
- $\quad$ Fig 5. In the Pertanyaan Tanya Meow page, user can choose the answer option based on the given question by choosing "Yes" or "No" button until Pertanyaan Tanya Meow page result appears.

- Fig. 6 Hasil Tanya Meow page is the result page of the answer to the question the user chose. This page provides information about the results of diseases suffered by cats based on the answers to questions that users choose.

- Fig. 7 Info Meow page is a page that displays articles that contain information on how to take care of cats. This page allows users to get articles quickly because they are organized by certain categories.

- Fig. 8 P3K is a page that displays articles that contain information about the first handling and prevention of cat diseases. This page provides users with information about what actions a user can take when their cat is sick.

- $\quad$ Fig. 9 Riwayat page will show a list of cat diseases that have been diagnosed. This page allows users to see the diagnosis of the disease that has been done.

\section{Evaluation}

After produced "Tanya Meow" application, The evaluation was done by distributing questionnaires to 30 respondents (users) based on the measurable 5 human factor theory and the conclusion that $91 \%$ users are satisfied with the features of the "Tanya Meow" application and assisting them in knowing cat's disease, adding insight on cat care and prevention and first aid to do when the cat is sick.

\section{Evaluation}

Based on analysis and evaluation conducted, the conclusion is as follows: by using "Tanya Meow" application, users can easily know the illness of their ailing cat based on the symptoms seen, get proper handling and first aid on their sick cat, can help users to get information about disease prevention should be done by the owner of the cat. For future work, there are some suggestions that need to be added to the "Tanya Meow" application as the following: Make data statistics about diseases that are often infected by cats based on users of Tanya Meow application that is connected online, and provide question and answer features with veterinarians and provide information on experienced veterinarians.

\section{Conflict of Interest}

The authors declare no conflict of interest.

\section{References}

[1] C. Hargrave. "Behavioural first aid for elderly cats and dog". Veterinary Nursing Journal, 26(11), 410-412, 2011.

[2] T. J. Howell, K. Mornement, P. C. Bennett. "Pet cat management practices among a representative sample of owners in Victoria, Australia". Journal of Veterinary Behavior: Clinical Applications and Research, 11, 42-49, 2016.

[3] T. V. Magazzu. "Pet Talk - First Aid". Courier Journal, 2014.

[4] S. J. Russell, P. Norvig. "Artificial intelligence: a modern approach". Malaysia; Pearson Education Limited, 2016.
[5] A. V. Saurkar, H. N. Watane. "An Expert Syatem For Diseases Diagnosis in Pet”. Advances in Medical Informatics, India, 2012.

[6] M. A. Suwed, R. M. Napitupulu. "Panduan Lengkap Kucing". Penebar Swadaya Grup, 2011.

[7] H. S. Wheirendrata. "Buku Pintar Kesehatan Kucing Ras". Yogyakarta: Lily Publisher, 2016.

[8] Y. Udjaja. "ANDROID APPLICATION FOR DETECTION OF SKIN CANCER USING EXPERT SYSTEM". Social Economics and Ecology International Journal (SEEIJ), 2(1), 2018.

[9] Y. Udjaja, V. S. Guizot, N. Chandra. "Gamification for Elementary Mathematics Learning in Indonesia". International Journal of Electrical and Computer Engineering, 8(5), 3859, 2018.

[10] Sasmoko, Y. Indrianti, S. A. Widhoyoko, Y. Udjaja, A. Tanurwijaya. "Teacher Engagement Interventions through ITEI Apps". In 2018 6th International Conference on Cyber and IT Service Management (CITSM) (pp. 1-4). IEEE, 2018.

[11] D. P. Kristiadi, Y. Udjaja, B. Supangat, R. Y. Prameswara, H. L. H. S. Warnars, Y. Heryadi, W. Kusakunniran. "The effect of UI, UX and GX on video games". In 2017 IEEE International Conference on Cybernetics and Computational Intelligence (CyberneticsCom) (pp. 158-163). IEEE, 2017.

[12] Y. Udjaja. "Ekspanpixel Bladsy Stranica: Performance Efficiency Improvement of Making Front-End Website Using Computer Aided Software Engineering Tool". Procedia Computer Science, 135, 292-301, 2018. 


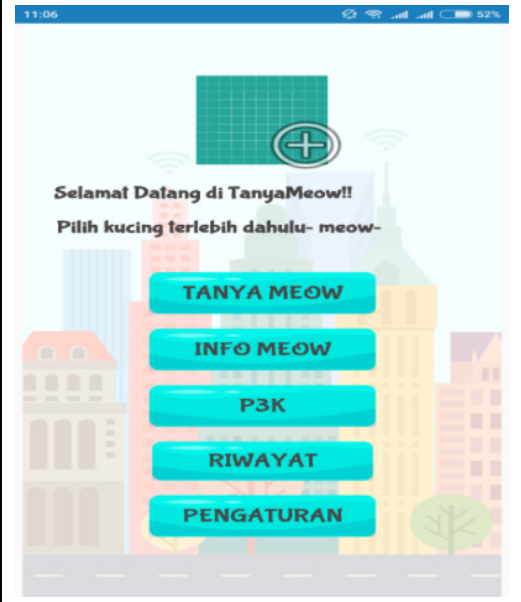

Figure 1: Main Menu Page

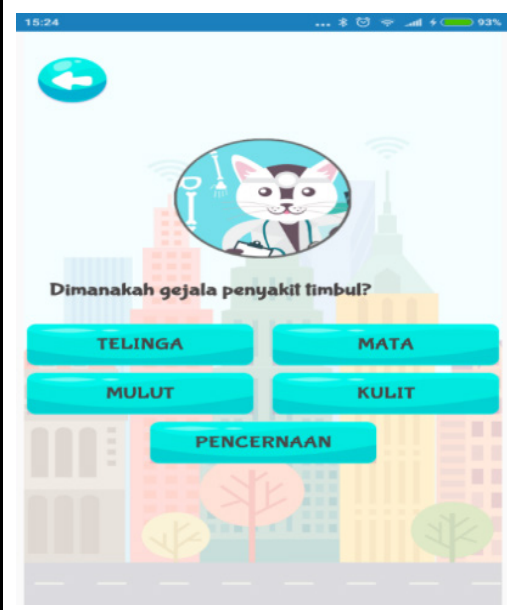

Figure 4: Tanya Meow Page

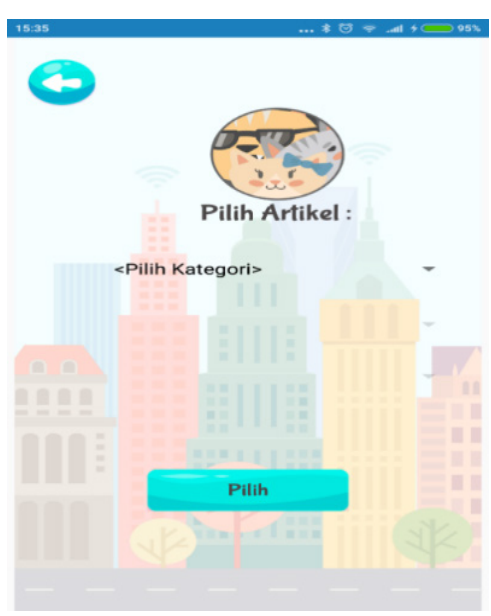

Figure 7: Article Page

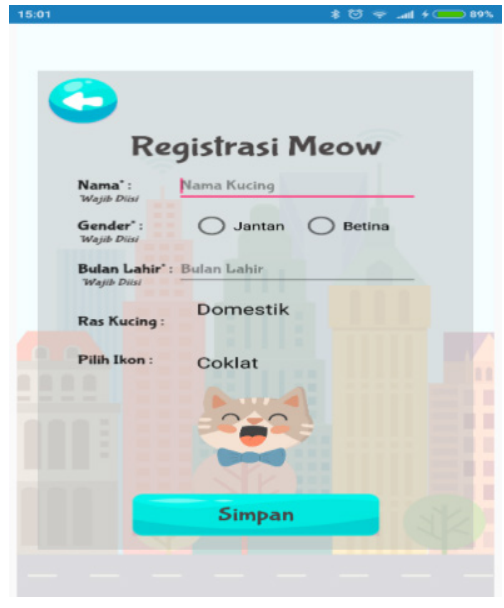

Figure 2: Registration Page

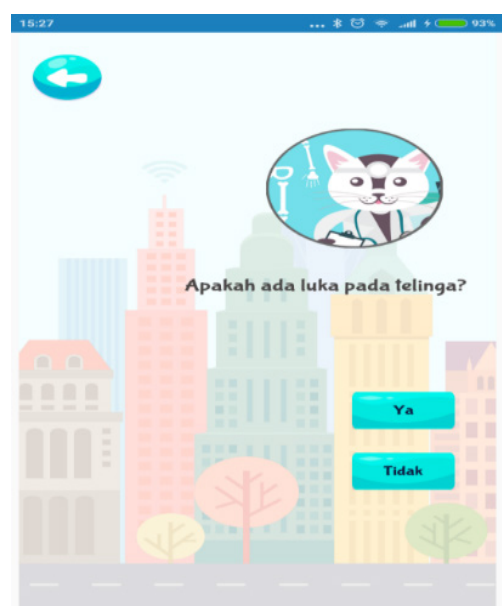

Figure 5: Question and Answer Page

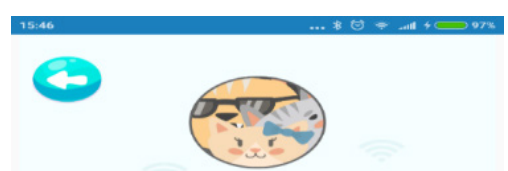

Pilih Artikel Penanganan Pertama :

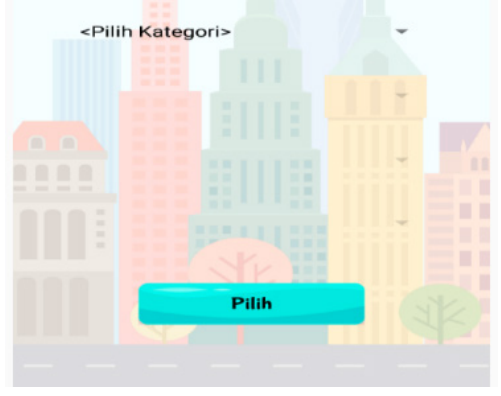

Figure 8: P3K Page

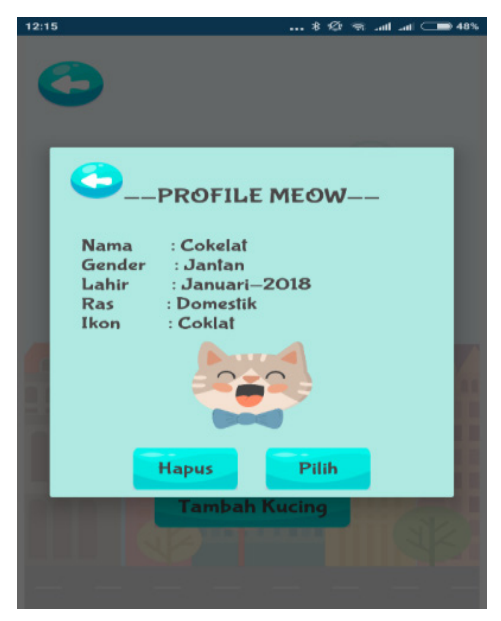

Figure 3: Cat's Profile Page

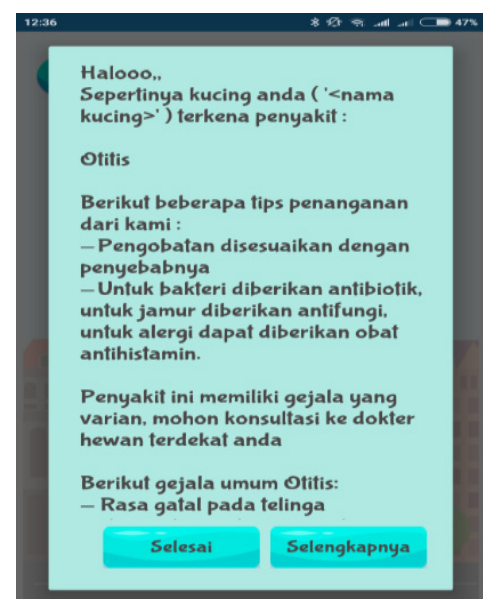

Figure 6: Result Page

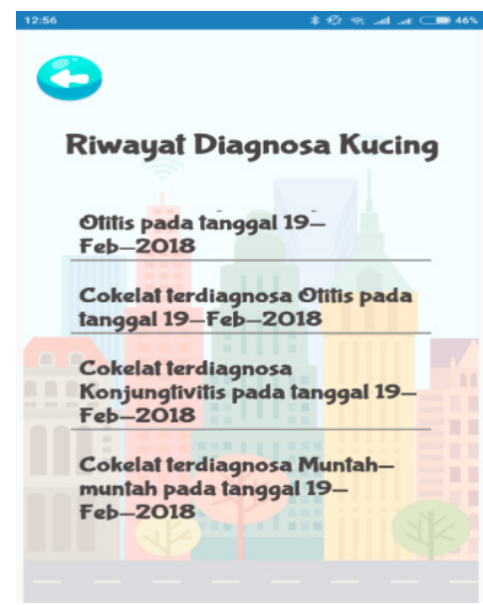

Figure 9: History Page 